\title{
Studi Eksploratif Problematika Pembelajaran Matematika Di Sekolah Dasar Di Tanah Datar
}

\section{Explorative Study Of Problematics Learning Mathematics In Basic Schools In Tanah Datar}

\author{
Lathifah Al Husna ${ }^{1}$, Zubaidah Amir MZ ${ }^{2}$, Rian Vebrianto ${ }^{3}$ \\ ${ }^{1}$ UIN Suska Riau, Pekanbaru, 21910125564@ students.uin-suska.ac.id \\ ${ }^{2}$ UIN Suska Riau, Pekanbaru, zubaidah.amir@ uin-suska.ac.id \\ ${ }^{3}$ UIN Suska Riau, Pekanbaru, rian.vebrianto@ uin-suska.ac.id
}

\begin{abstract}
ABSTRAK
Penelitian ini bertujuan untuk mengidentifikasi informasi mengenai problematika pembelajaran Matematika di Sekolah Dasar. Penelitian ini merupakan penelitian studi kasus. Penelitian ini melibatkan tujuh orang responden yang terdiri dari dua guru, dua siswa dan tiga orang tua siswa di sekolah dasar di Tanah Datar. Untuk tujuan kerahasiaan, responden diberi inisial R1, R2, R3, R4, R5 , R6, dan R7. Teknik pengumpulan data menggunakan google form dan diperkuat oleh artikel terkait. Hasil dari penelitian ini yaitu adanya banyak problematika yang dialami oleh guru, siswa dan orang tua siswa dalam pembelajaran matematika di sekolah dasar, yaitu siswa tidak memahami materi yang disampaikan oleh guru, guru hanya menjelaskan materi sebentar saja, guru ikut serta memantu siswa mengerjakan latihan yang diberikannya, guru tidak menanyakan pemahaman siswa terhadap materi yang diajarkan, guru tidak menggunakan media pembelajaran yang baik, siswa tidak bisa berpikir matematis meskipun telah duduk di kelas tinggi, ide-ide siswa tidak keluar dan jadi terpendam, siswa yang tidak bertanya terhadap materi yang dijelaskan oleh guru, metode yang digunakan oleh guru masih metode lama, serta minat dan kemampuan siswa yang kurang meningkat.
\end{abstract}

Kata kunci: Problematika, pembelajaran matematika, studi eksploratif

\begin{abstract}
This study aims to identify information about the problems of learning mathematics in elementary schools. This research is a case study research. This study involved seven respondents consisting of two teachers, two students and three parents of students in elementary schools in Tanah Datar. For confidentiality purposes, respondents were given the initials R1, R2, R3, R4, R5, R6, and R7. Data collection techniques use google form and are strengthened by related articles. The results of this study are that there are many problems experienced by teachers, students and parents in mathematics learning in elementary schools, namely students do not understand the material presented by the teacher, the teacher only explains the material for a short time, the teacher participates in helping students do the exercises $\mathrm{He}$ gave, the teacher did not ask students 'understanding of the material being taught, the teacher did not use good learning media, students could not think mathematically even though they were in high class, students' ideas did not come out and became hidden, students did not ask questions about the material explained by the teacher, the method used by the teacher is still the old method, and the interests and abilities of students have not increased.
\end{abstract}

Keywords: Problems, mathematics learning, exploratory study 
How to Cite: Husna, L. A., MZ, Z. A., \& Vebrianto, R. (2021). Explorative Study Of Problematics Learning Mathematics In Basic Schools In Tanah Datar. Mathline: Jurnal Matematika dan Pendidikan Matematika, Vol. 6 No. 1, 1 $-12$.

DOI: $\underline{\text { https://doi.org/10.31943/mathline.v6i1.159 }}$

\section{PENDAHULUAN}

Peranan pendidikan sangat penting dalam meningkatkan dan mengembangkan kualitas manusia dari berbagai macam aspek. Salah satu cara untuk meningkatkan dan mengembangkan kualitas manusia tersebut adalah dengan adanya pembelajaran matematika dimana pembelajaran matematika memungkinkan sebagai salah satu jalan dalam penyusunan pemikiran yang jelas, tepat dan teliti. Selain sebagai pelayan ilmu, matematika juga digunakan dalam banyak bidang ilmu pengetahuan, terutama dalam bidang perkembangan teknologi seperti yang ada pada saat sekarang ini. Dengan demikian, penguasaan matematika sangat diperlukan oleh peserta didik secara tuntas. Untuk mencapai tujuan pembelajarannya, kegiatan pembelajaran matematika perlu mendapat perhatian yang lebih.

Sumatini, Sahudin, dan Damaningsih (Sari, 2019) menjelaskan bahwa peranan penting matematika ada dalam segala aspek kehidupan. Matematika adalah proses yang mencakup dua kegiatan yang tidak bisa dipisahkan yaitu belajar dan mengajar. Dua kegiatan itu dipadukan menjadi satu kegiatan dimana kegiatan itu menghasilkan proses belajar mengajar yang terdapat interaksi belajar antara guru dengan peserta didik serta sesame peserta didik. Proses pembelajaran adalah proses yang sangat penting dalam dunia pendidikan serta patut patut mendapat perhatian, perencanaan dan persiapan, karena pembelajaran merupakan faktor utama penentu keberhasilan pendidikan. Proses pembelajaran matematika berkaitan dengan konsep yang banyak. Matematika juga memiliki satu konsep yang terhunbung dengan konsep lainnya. Akibatnya, peserta didik beranggapan bahwa matematika memiliki sifat yang abstrak yang mengakibatkan matematika menjadi mata pelajaran yang dianggap sulit.

Hal lain yang terjadi adalah kurikulum matematika yang digunakan saat ini padat dengan materi. Adanya target untuk menyelesaikan materi yang padatm menyebabkan guru merasa selalu terbebani. Jika dianalogikan, "bahan pembicaraan yang hangat di kalangan guru matematika apalagi ketika mereka bertemu adalah mengenai materi yang mereka ajarkan di kelasnya masing-masing, sampai dimana materi yang mereka ajarkan. 
Mereka tidak mendiskusikan tentang bagaimana cara menjajikan pelajaran matematika dengan menarik."

Pada hakikatnya, matematika merupakan pelajaran yang mengedepankan penalaran. Namun, kenyataan yang ada saat ini adalah pembelajaran matematika sudah berubah menjadi pelajaran yang dipenuhi dengan hafal-mengahafal. Pelajaran matematika disamakan dengan pelajaran lain yang sifatnya hafalan. Sehingga pembelajaran matematika yang ada saat ini adalah pembelajaran dengan sistem guru berdiri menyampaikan pembelajaran dengan berceramah di depan kelas atau "berbicara dan menulis" dengan papan tulisnya, lalu muridnya mencatat dan menghafal.

Permasalahan lainnya yang muncul dalam pembelajaran matematika adalah pendapat peserta didik bahwa matematika merupakan ilmu penetahuan yang tidak bermanfaat. Ini merupakan suatu hal yang sangat menyedihkan. Merupakan hal yang wajar jika matematika bersifat abstrak dan sulit dicerna. Adalah kewajiban bagi seorang guru untuk selalu berusaha mengajarkan matematika dengan cara yang akan membuat persepsi peserta didik berubah. Seperti dengan cara menunjukkan hubungan matematika dengan kehidupan nyata. Dikarenakan pandangan siswa tentang mamfaat matematika yan tidak ada, siswa mengalami penurunan motivasi, bahkan kehilangan motivasi tersebut. Sehingga mereka memutuskan untuk mengafal matematika, buka mempelajarinya (Sukasno, 2012).

Pelajaran matematika merupakan salah satu mata pelajaran yang dipelajari oleh siswa mulai dari jenjang SD hingga perguruan tinggi. Oleh sebab itu, peranan pelajaran matematika sangat penting. Jika siswa mempelajari matematika dengan cara yang benar, maka kemampuan penalaran siswa akan meningkat. Akan tetapi, keluhan siswa terhadap mata pelajaran ini masih sangat banyak. Kebanyakan siswa SD menganggap bahwa matematika adalah mata pelajaran yang sulit. Matematika juga dipandang sebagai mata pelajaran yang menakutkan, tidak menarik, dan juga membosahnkan. (Sukasno, 2012).

Pernyataan lain yang muncul adalah "Matematika itu susah." Pernyataan ini merupakan hal yang lumrah di kalangan peserta didik. Terlebih bagi siswa yang benarbenar tidak menyukai matematika, mereka beranggapan bahwa matematika yang merupakan ilmu pasti ini adalah pelajaran yang rumit, membingungkan, dan bikn pusing saja. Akibatnya, mereka akan malas belajar matematika.

Kesulitan lain yang muncul dalam pembelajaran matematika di SD adalah kemampuan dalam pemecahan masalah, sebagaimana yang dikutip dari penelitian (Phonapichat et al., 2013), berdasarkan hasil wawancara denga guru matematika 
menunjukkan bahwa, 1) Ketidakmampuan siswa dalam membaca teks dan kesulitan ketika pembacaan sehingga menimbulkan kesulitan pemecahan masalah matematika, 2) Kesalahan siswa dalam mengartikan teks, 3) Ketidaksukaan siswa terhadap soal yang panjang, 4) Ketidaksukaan siswa terhadap soal yang panjang memahami suatu masalah, mereka suka menebak-nebak dan tidak menggunakan proses berpikir matematis, 5) Siswa tidak mau untuk bersabar dan tidak suka untuk membaca soal, 6) Siswa tidak mampu untuk memikirkan apa yang harus diasumsikan dan apa informasi dari masalah yang diperlukan untuk memecahannya, dan 7) Kesulitan siswa dalam memahami kata kunci dalam masalah, sehingga tidak dapat menjelaskannya dalam bentuk simbol.

Penelitian ini berfokus pada problematika dalam pembelajaran matmatika di sekolah dasar yang ada di Kabupaten Tanah Datar. Oleh karena itu penelitian ini bertujuan untuk unuk mengidentifikasi dan mendapatkan informasi mengenai problematika pembelajaran Matmatika di Sekolah Dasar.

\section{METODE PENELITIAN}

Penelitian ini merupakan penelitian studi kasus. Metode yang digunakan dalam penelitian ini adalah metode studi kasus eksplorasi dan pendekatan penelitian yang digunakan adalah metode studi kasus kualitatif yang digunakan untuk mendapatkan informasi mengenai problematika pembelajaran matematika di SD. Penelitian ini melibatkan tujuh orang responden yang terdiri dari dua guru, dua siswa dan tiga orang tua siswa sekolah dasar di Tanah Datar. Demi kerahasiaan, responden diberi inisial R1, R2, R3, R4, R5 , R6, dan R7.

Tabel 1. Profil Responden

\begin{tabular}{ccccc}
\hline Inisial & Jenis Kelamin & Usia & Jabatan & Pendidikan \\
\hline R1 & Laki-laki & 52 Tahun & Guru & S1 \\
R2 & Laki-laki & 50 tahun & Guru & S1 \\
R3 & Laki-laki & 11 tahun & Siswa & SD \\
R4 & Perempuan & 10 Tahun & Siswa & SD \\
R5 & Perempuan & 42 tahun & Orang Tua & S1 \\
R6 & Perempuan & 40 tahun & Orang Tua & S3 \\
R7 & Perempuan & 44 Tahun & Orang Tua & S1 \\
\hline
\end{tabular}

Pengumpulan data dilakukan melalui google form dan diperkuat oleh artikel yang terkait. Responden untuk penelitian ini terdiri dari dua orang guru, dua orang siswa dan tiga orang wali murid di sekolah dasar yang ada di Tanah Datar. Metode pengumpulan 
dengan primer dengan pengisian data lewat google form, sedangkan data sekunder dikumpulkan dengan melirik kepada artikel terkait. Penelitian ini dilakukan terhadap tujuh responden yang ada di Tanah Datar. Penelitian ini dilakukan dari bulan Oktober hingga November melalui google formulir. Untuk mendapatkan informasi mengenai problematika pembelajaran matematika di sekolah dasar, diajukan pertanyaan berikut: Jelaskan hambatan atau permasalahan yang dialami dalam kegiatan pembelajaran matematika di sekolah dasar (jawab sesuai jabatan)!

\section{HASIL DAN PEMBAHASAN}

Tujuan dari penelitian ini adalah untuk mengidentifikasi dan mendapatkan informasi mengenai problematika pembelajaran Matematika di Sekolah Dasar yang ada di Tanah Datar. Tanggapan Semua responden merupakan kutipan asli, dan telah dikutip berdasarkan pernyataan para responden di google formulir. Berikut adalah hasil penelitian yang didapatkan oleh peneliti:

Responden 1 (R1) menjawab: "Guru membantu siswa mengerjakan latihan yang diberikan olehnya sendiri, karena jika tidak diberikan arahan atau bantuan, siswa tidak paham dan tidak mengerjakan latihan dengan baik". Responden 2 (R2) menjawab: "Setelah guru memberikan materi pelajaran, siswa tidak bertanya sehingga guru menganggap siswa tersebut telah paham, padahal sebenarnya tidak paham. Siswa menganggap bahwa matematika merupakan pelajaran yag susah untuk dipelajari."

Responden 3 (R3) menjawab: “Guru saya hanya menjelaskan materi, lalu kami disuruh membuat tugas. Tidak ditanya apakah kami paham atau tidak." Responden 4 (R4) menjawab: "Saya tidak paham dengan materi yang diajarkan oleh guru saya. Guru hanya menjelaskan materi sebentar, lalu kami disuruh untuk mengerjakan tugas atau menghapal perkalian. Sehingga saya tidak berminat untuk belajar matematika." Responden 5 (R5) menjawab: "Anak saya tidak meningkat minatnya dan kemampuannya dalam pembelajaran matematika karena anak saya sering mengeluhkan bahwa gurunya tidak mejelaskan materi pembelajaran dengan baik. Tidak ada media pembelajaran lain yang digunakan oleh guru anak saya selain buku pelajaran.”

Responden 6 (R6) menjawab: Anak saya tidak mampu untuk berpikir matematis, meskipun sudah duduk di kelas tinggi (kelas VI). Dia kesulitan dalam menyelesaikan soal-soal latihan matematika terutama berkaitan dengan soal cerita, sehingga tidak ada ide yang keluar." Responden 7 (R7) menjawab: "Minat anak saya dalam belajar matematika sangat rendah karena di sekolah pembelajaran hanya menggunakan metode 

Datar

lama. Gurunya hanya ceramah di depan kelas tanpa menggunakan media yang lain. Guru hanya menjelaskan satu bentuk materi, lalu menyuruh siswa untuk mengerjakan latihan-latihan yang bentuknya berbeda dengan yang dijelaskan oleh guru tersebut. Hal ini mengakibatkan siswa harus berusaha untuk berpikir lebih dalam tanpa dibimbing oleh guru. Dan akhirnya, hasil belajar tidak sesuai dengan yang diharapkan."

Pembelajaran matematika di Sekolah Dasar (SD) memiliki banyak problematika, baik itu yang datang dari guru bidang studi, siswa, maupun orang tua siswa itu sendiri. Berdasarkan data yang didapat oleh peneliti melalui google form dari beberapa orang guru, siswa dan orang tua siswa berkaitan dengan masalah yang dialami dalam pemebajaran matematika di SD, didapatlah bahwa masalah-masalah tersebut di antaranya: siswa tidak memahami materi yang disampaikan oleh guru, guru hanya menjelaskan materi sebentar saja, guru ikut serta membantu siswa mengerjakan latihan yang diberikannya, guru tidak menanyakan pemahaman siswa terhadap materi yang diajarkan, guru tidak menggunakan media pembelajaran yang baik, siswa tidak bisa berpikir matematis meskipun telah duduk di kelas tinggi, ide-ide siswa tidak keluar dan jadi terpendam, siswa yang tidak bertanya terhadap materi yang dijelaskan oleh guru, metode yang digunakan oleh guru masih metode lama, serta minat dan kemampuan siswa yang kurang meningkat.

Hal ini senada dengan beberapa masalah yang didaptkan dari beberapa artikel terkait, yaitu: kemampuan siswa yang kurang pada bagian pemecahan masalah misalnya dalam penyelesaian masalah pada soal cerita, siswa yang tidak tidak terbiasa secara rutin untuk mngerjakan latihan dan ini menyebabkan siswa kesulitan dalam penyelesaian soal tersebut, kekurangan siswa dalam pemahaman mengenai maksud soal cerita matematika merupakan faktor kemampuan pemecahan masalah yang rendah, dan guru juga ikut membantu siswa untuk mendapatkan pemahamanketika mengerjakan soal cerita, guru juga berpendapat bahwa siswa akan kesulitan mengerjakan soal jika guru tidak ikut membantu (S. Widodo \& Kartikasari, 2017).

Dalam (Sudarman, 2016), masalah yang dialami dalam pembelajaran matematika di sekolah dasar, yaitu kesulitan yang dialami oleh kebanyakan siswa dalam penyelesaian soal cerita matematika, siswa takut bertanya tentang hal yang sulit dan tidak dipahaminya, anggapan siswa bahwa matematika merupakan pelajaran yang menakutkan. Serta guru masih mengalami kesulitan dan kendala dalam perancangan dan pemilihan masalah yang 
kontekstual. Ketidakmampuan siswa untuk berpikir abstrak dan kekurangan dalam pemahaman membaca juga menjadi masalah dalam pembelajaran matematika.

Sukasno (2012) menjelaskan bahwa rendahnya atau kurangnya minat siswa terhadap pelajaran matematika dengan sistem guru berdiri menyampaikan pembelajaran dengan berceramah di depan kelas atau "berbicara dan menulis" dengan papan tulisnya, lalu muridnya mencatat dan menghafal. Yang aktif dalam pembelajaran adalah guru dalam penyampaian informasi, sedangkan siswa pasif dengan hanya menyimak, mencatat lalu mengerjakan tugas. Selanjutnya, adanya Penggunaan dwi kurikulum (2 kurikulum) yang menyebabkan rendahnya kemampuan siswa dalam penerimaan materi pelajaran Matematika dan kurang meningkatnya kemampuan siswa yang disebabkan oleh kepasifan siswa dalam pembelajaran. (S. T. Widodo \& Rahmawati, 2018).

Kesulitan yang dialami siswa dalam pembelajaran juga disebabkan oleh kesulitan yang dialami guru dalam mengajar siswanya tentang bagaimana menyelesaikan masalah dalam matematika (soal cerita). Munculnya kesulitan tersebut karena pandangan bahwa satu-satunya tujuan dari pemecahan masalah itu adalah jawaban akhir. Mata pelajaran yang terpadu dalam tematik yang tidak diajarkan atau tidak sampai seluruhnya kepada siswa dan kesulitan guru dalam mengajarkan materi secara lebih luas dan lebih dalam juga menjadi problematika pembelajaran (Warda, 2017).

Dari pernyataan dan pendapat dari 7 responden di atas, akan dijelaskan dan dibahas sebagai berikut:

\section{Problematika Pembelajaran Matematika di bidang Metode pembelajaran}

Metode pembelajaran yang digunakan dalam belajar matematika di Sekolah Dasar hanya metode konvensional. Tidak ada metode lain yang digunakan, sehingga siswa merasa bosan dengan cara mengajar guru. Guru hanya sibuk berceramah menjelaskan materi pembelajaran matematika di depan kelas dengan menggunakan papan tulis, tanpa tau bahwa siswanya paham atau tidak dengan materi yang dijelaskannya. Hal ini menjadi problematika dalam pembelajaran matematika.

Metode konvensional juga sering disebut dengan metode tradisional, yang identik dengan metode ceramah, yaitu guru berdiri di depan kelas menyampaikan materi pembelajaran sedangkan siswa mendengarkan. Metode konvensional seperti itu memiliki kelebihan, namun itu semua tidak bisa membuktikan bahwa metode kovensional dapat digunakan untuk digunakan dalam pembelajaran matematika secara efektif dan efisien di zaman sekarang. 
Menurut Nasution dalam (Zulyadaini, 2016), ada beberapa ciri-ciri Model pembelajaran konesional, yaitu:

1. Perumusan tujuan yang tidak spesifik.

2. Penyajian bahan pelajaran hanya kepada keseluruhan kelas secara perkelompok, individual siswa tidak diperhatikan.

3. Bahan pelajaran tergantung kepada pertimbangan guru. Sebagian besarnya berbentuk ceramah, kuliah, tugas tertulis, dan lain-lainnya.

4. Kebanyakan siswa bersikap pasif, karena siswa hanya mendengarkan penjelasan dari guru.

5. Peran utama guru adalah sebagai penyalur pengetahuan.

6. Penentuan nilai hasil belajar siswa untuk satu semester berdasarkan kepada hasil dari beberapa test yang dilaluinya.

Menurut hasil penelitian (Astuti, 2015) bahwa penggunaan metode modern dalam pembelajaran matematika lebih meningkatkan hasil belajar matematika siswa dari pada penggunaan metode konvensional dengan metode ceramah dalam pembelajaran. Berdasarkan penelitian yang dilakukan oleh (Nuraisah et al., 2016), bahwa kemampuan berpikir kritis matematis siswa tidak dapat ditingkatkan secara signifikan dengan pembelajaran matematika secara konvensional, karena rasa bosan yang dirasakan siswa terhadap metode pembelajaran yang hanya melibatkan keaktifan guru tanpa melibatkan keaktifan mereka saat proses pembelajaran berlangsung. Motivasi siswa dalam belajar juga tidak bisa ditingkatkan secara signifikan dengan pembelajaran matematika yang dilakukan dengan metode konvensional.

\section{Problematika Pembelajaran Matematika di bidang Media Pembelajaran}

Media pembelajaran yang digunakan hanya buku pembelajaran membuat siswa tidak termotivasi, dan meningkat minat dan keinginannya untuk belajar matematika. Karena guru hanya menyajikan materi menggunakan buku pelajaran saja, tidak dibantu dengan menggunakan media atau sarana dan alat bantu yang lain. Media pembelajaran juga merupakan permasalahan dalam pembelajaran matematika.

Media pembelajaran merupakan segala sesuatu yang berupa fisik ataupun teknis dalam proses pembelajaran yang gunanya untuk membantu dan mempermudah guru dalam penyampaian materi pelajaran kepada siswa (Adam \& Syastra, 2015). 
Menurut Hamalik (Tafonao, 2018) media pembelajaran memiliki ciri-ciri umum, yaitu:

1. Identik dengan kata "peragaan" yang asal katanya adalah "raga", yang berarti benda yang dapat dipegang, dilihat dan didengar serta diamati oleh panca indera.

2. Point utama media pembelajaran adalah berkaitan dengan benda atau hal yang melibatkan indra penglihatan dan indra pendengaran.

3. Kegunaan media pembelajaran sebagai perantara komunikasi guru dan siswa.

4. Sebagai alat bantu dalam mengajar di kelas dan luar kelas.

5. Digunakan dalam kegiatan pembelajaran.

6. Media pembelajaran sangat berkaitan dengan metode pembelajaran.

Media Pembelajaran memiliki pengaruh yang penting untuk keberlangsungan pembelajaran matematika. Berdasarkan penelitian (Samura, 2015) tentang penggunaan media yang digunakan dalam materi bangun datar pembelajaran geometri, menghasilkan data bahwa adanya kemudahan siswa dalam memahami dan mengkonstruksi konsep materi pembelajaran, serta adanya motivasi siswa dalam belajar.

Selanjutnya penelitian (Yuliana \& Budianti, 2015) menunjukkan bahwa hasil beajar matematika mengalami peningkatan dan lebih unggul menggunakan media pembelajaran (media konkret) jika dibandingkan dengan pembelajaran tanpa menggunakan media pembelajaran (dalam hal ini, medianya adalah media konkret). Agar menghasilkan perubahan tingkah laku seperti yang diharapkan, media pembelajaran menjadi suatu kebutuhan dalam rangka kesuksesan program belajar siswa (Mahnun, 2012).

\section{Problematika Pembelajaran Matematika di bidang Strategi Pembelajaran}

Siswa yang tidak memahami penyampaian materi oleh guru disebabkan penyampaian materi yang sebentar saja tanpa mengetahui apakah siswanya paham atau tidak, menandakan guru terseut tidak menggunakan strategi dalam pembelajaran dilakukan. Hal inilah yang memicu siswa merasaan kesulitan atau adanya hambatan bagi siswa dalam belajar matematika. Apalagi siswa sekolah dasar yang masih memerlukan banyak arahan dan penjelasan sebagai salah satu unsur untuk mengasah kemampuan belajar matematika mereka.

Strategi pembelajaran bertujuan untuk belajar secara maksimal agar siswa memiliki hasil belajar yang optimal. Strategi pembelajaran berperan sebagai pola yang bertujuan untuk mendapatkan hasil yang maksimal yang digunakan oleh guru sebelum pembelajaran dimulai. Hasil yang maksimal itu berupa penguasaan siswa yang maksimal 
terhadap semua materi yang diajarkan oleh guru, di sisi lain adalah adanya kepuasan batin yang didapatkan oleh guru dari hasil tersebut. Melakukan proses pembelajaran dengan selalu semangat dan senang, tanpa adanya tekanan dan rasa lelah hingga akhir juga merupakan hasil yang diharapkan dari penggunaan stategi pembelajaran.

Perumusan strategi pembelajaran sangat penting dirancang sebelum pembelajaran dilaksanakan. Jika strategi pembelajaran yang akan dirancang tidak sesuai dengan kondisi kelas, karakteristik siswa yang diajar serta materi yang akan diajar, maka perancangan ulang strategi pembelajaran perlu dilakukan. Hal ini dikarenakan tugas guru adalah membimbing siswa untuk memperoleh hasil belajar yang optimal Sebaliknya, siswa merupakan orgasme yang selalu mengalami perubahan dan perkembangan, yang memiliki banyak keadaan dan kondisi seperti senang, sedih, ada yang sedang tersenyum dan tertawa saat yang lain sedang murung dan marah, sedangkan peristiwa belajar itu merupakan sebuah peristiwa psikologis (Barlian, 2013).

Suatu kegiatan pembelajaran yang bertujuan untuk menghasilkan pembelajaran yang efektif serta efisien merupakan strategi pembelajaran. Strategi pembelajaran akan berbeda bergantung kepada pendekatan yang digunakan. Terdapat banyak strategi pembelajaran yang digunakan untuk menerapkan pembelajaran, sedangkan penerapannya akan berbeda bergantung kepada pendekatan yang digunakan oleh guru tersebut. (Firmansyah, 2015).

Strategi pembelajaran memiliki pengaruh yang besar dalam meningkatkan hasil pembelajaran matematika, sebagaimana penelitian (Dipayana et al., 2014) yang menghasilkan bahwa penggunaan strategi pembelajaran pada pembelajaran matematika akan meningkatkan skor hasil belajar, serta terdapat hasil belajar matematika dipengaruhi oleh keberadaan strategi pembelajaran.

\section{KESIMPULAN}

Berbagai jenis problematika dalam pembelajaran matematika terutama di sekolag dasar, diantaranya: ketidakpahaman siswa terhadap materi yang disampaikan oleh guru, guru hanya menjelaskan materi sebentar saja, guru ikut serta memantu siswa mengerjakan laihan yang diberikannya, guru tidak menanyaan pemahaman siswa trhadap materi yang diajarkan, ketiadaan pengunaan media pembelajaran dalam oleh guru, siswa tidak bisa berpikir matematis meskipun telah duduk di kelas tinggi, ide-ide siswa tidak keluar dan jadi tependam, siswa yang tidak bertanya trhadap materi yang dijelaskan oleh guru, 
metode yng digunakakn oleh guru masih metode lama, serta minat dan kemampuan siswa yang kurang meningkat.

\section{DAFTAR PUSTAKA}

Adam, S., \& Syastra, M. T. (2015). Pemanfaatan Media Pembelajaran Berbasis Teknologi Informasi Bagi Siswa Kelas X Sma Ananda Batam. CBIS Journal, 3(2), 78-90.

Astuti, N. D. (2015). Pengaruh Metode terhadap Hasil Belajar Matematika Ditinjau dari Kemandirian Belajar Siswa. Elementary, 1(2), 31-35

Barlian, I. (2013). Begitu Pentingkah Strategi Belajar Mengajar bagi Guru? Jurnal Forum Sosial, VI(1), 241-246.

Dipayana, I. D., Japa, I. G. N., \& Suarjana, I. (2014). Pengaruh Strategi Pembelajaran Rotating Trio Exchange (RTE) terhadap Hasil Belajar Matematika. Jurnal Mimbar PGSD Universitas Pendidikan Ganesha Jurusan PGSD, 2(1).

Firmansyah, D. (2015). Pengaruh Strategi Pembelajaran Dan Minat Belajar Terhadap Hasil Belajar Matematika. [Jurnal Pendidikan Unsika, 3(1), 34-44.

Mahnun, N. (2012). Media Pembelajaran (Kajian terhadap Langkah-langkah Pemilihan Media dan Implementasinya dalam Pembelajaran). An-Nida', Jurnal Pemikiran Islam, 37(1), 27-35.

Nuraisah, E., Irawati, R. \& Hanifah, N. (2016). Perbedaan Pengaruh Penggunaan Pembelajaran Konvensional dan Pendekatan Kontekstual terhadap Kemampuan Berpikir Kritis Matematis dan Motivasi Belajar Siswa Pada Materi Pecahan. Jurnal Pena Ilmiah, 1(1), 291-300.

Phonapichat, P., Wongwanich, S., \& Sujiva, S. (2013). An Analysis of Elementary School Students' Difficulties in Mathematical Problem Solving. Procedia - Social and Behavioral Sciences, 116(2014), 3169-3174.

Samura, A. O. (2015). Penggunaan Media dalam Pembelajaran Matematika dan Manfaatnya. Delta-Pi: Jurnal Matematika dan Pendidikan Matematika, 4(1), 69-79.

Sari, R. K. (2019). Analisis Problematika Pembelajaran Matematika di Sekolah Menengah Pertama dan Solusi Alternatifnya. Prismatika: Jurnal Pendidikan Dan Riset Matematika, 2(1), 23-31.

Sudarman, S. W. (2016). Analisis Problematika Pendidikan Matematika Berupa Soal Cerita pada Siswa SD. Aksioma Jurnal Pendidikan Matematika FKIP Univ. Muhammadiyah Metro, 5(2), 161-171.

Sukasno. (2012). Problematika Pembelajaran Matematika di SD. Jurnal Perspektif Pendidikan, 5(1).

Tafonao, T. (2018). Peranan Media Pembelajaran dalam Meningkatkan Minat Belajar Mahasiswa. Jurnal Komunikasi Pendidikan, 2(2), 103-114. 
Warda, M. K. (2017). Problematika Implementasi Pembelajaran Tematik Terpadu pada Mata Pelajaran Matematika dalam Kurikulum 2013 di SD Muhammadiyah 24 Gajahan Surakarta.

Widodo, S., \& Kartikasari. (2017). Pembelajaran Pemecahan Masalah Matematis Siswa Sekolah Dasar dengan Model Creative Problem Solving (CPS). Jurnal Prisma Universitas Suryakancana Pembelajaran, VI(1), 57-65.

Widodo, S.T. \& Rahmawati, I. (2018). Problematika Pembelajaran Matematika dengan Implementasi Dwi-Kurikulum pada Kelas VI SDN Sumberingin Jombang. JPGSD, 6(2), 89-98.

Yuliana, N. D., \& Budianti, Y. (2015). Pengaruh Penggunaan Media Konkret terhadap Hasil Belajar Siswa pada Mata Pelajaran Matematika Kelas II Sekolah Dasar Negeri Babelan Kota 06 Kecamatan Babelan Kabupaten Bekasi. Pedagogik, III(1), 34-40.

Zulyadaini. (2016). Perbandingan Hasil Belajar Matematika Model Pembelajaran Kooperatif Tipe Coop-Coop dengan Konvensional. Jurnal Ilmiah Universitas Batanghari Jambi, 16(1), 153-158. 